\title{
PERLINDUNGAN HUKUM MASYARAKAT HUKUM ADAT ATAS HUTAN ADAT
}

\author{
Safrin Salam \\ Fakultas Hukum Universitas Muhammadiyah Buton \\ Dosen Hukum Adat \\ Email: salamsafrin2@gmail.com
}

\begin{abstract}
ABSTRAK
Perlindungan hukum masyarakat hukum adat atas hutan adat merupakan kewajiban pemerintah yang harus dipenuhi sebagaimana yang diatur dalam Pasal 18B UUD 1945. Fokus permasalahan yang dibahas dalam penelitian ini adalah bagaimana prinsip-prinsip pengaturan Hutan Adat berdasarkan Putusan Mahkamah Konstitusi No. 35/PUU-IX/2011 dan Bagaimana peran pemerintah daerah dalam mewujudkan Perlindungan Hukum Masyarakat Hukum Adat pasca Putusan Mahkamah Konstitusi No. 35/PUU-IX/2011.Hasil penelitian menunjukan bahwa Prinsip-Prinsip Pengaturan Hutan Adat dalam Putusan Mahkamah Konstitusi No. 35/PUU-IX/2011 adalah: a) Hutan adat terpisah dari Hutan Negara; b) Hutan adat merupakan hutan hak; c) Definisi Hutan adat adalah hutan yang berada dalam wilayah masyarakat hukum adat, dan; d) hutan adat merupakan hak yang dimiliki oleh masyarakat hukum adat. Sedangkan peran pemerintah daerah dalam mewujudkan perlindungan hukum masyarakat hukum adat atas hutan adat pasca Putusan Mahkamah Konstitusi No. 35/PUU-IX/2011 adalah dengan menerbitkan surat keputusan kepala daerah tentang pengakuan, perlindungan masyarakat hukum adat dan wilayahnya termasuk didalamnya hutan adat
\end{abstract}

Kata Kunci: Perlindungan Hukum, Masyarakat Hukum Adat, Hutan Adat

\section{ABSTRACT}

Legal protection of customary (adat) law community on customary (adat) forests is government's obligation that must be fulfill based on Article 18B of the 1945 Constitution. This research focuses on how the principles of customary forest set by the Constitutional Court Decision No. 35/PUU-IX/2011 and the role of local government in realizing the legal protection of customary (adat) law community after the Constitutional Court Decision No. 35/PUU-IX/2011. The results show that the regulation principles of customary forests in the Constitutional Court Decision No. 35/PUU-IX/2011 are: a) the customary forests are separated from the state forests; $b$ ) the customary forests are private forests; c) the customary forests are forests within adat law community territories, and d) the customary (adat) law community own the customary forests as their rights. While the role of local governments in realizing the legal protection of indigenous people on customary forests after the Constitutional Court Decision No. 35/PUU-IX/2011 is to publish a decree of the head of the region about the recognition and protection of customary (adat) law community and their territories including the customary forests. 


\section{Keywords: Legal Protection, Customary (Adat) law community, Customary Forests}

\section{A. PENDAHULUAN}

Undang-Undang Dasar Negara Republik Indonesia Tahun 1945 pada Pasal 18B ayat (2) telah menjamin keberadaan masyarakat hukum adat dengan memberikan pengakuan bersyarat. Pada penelitian ini istilah masyarakat hukum adat mengutip pendapat ahli dari Hazairin yang mengatakan bahwa masyarakat hukum adat adalah kesatuan-kesatuan masyarakat yang mempunyai kelengkapankelengkapan untuk sanggup berdiri sendiri yang mempunyai kesatuan hukum, kesatuan penguasa, dan kesatuan lingkungan hidup berdasarkan hak bersama atas tanah dan air bagi semua anggotanya (Simarmata, 2006: 23). Pendapat tersebut juga diperkuat oleh pendapat Ade Saptomo yang menyatakan bahwa masyarakat adat merupakan suatu kesatuan masyarakat bersifat otonom, yaitu mereka mengatur sistem kehidupannya (hukum, politik, ekonomi, dsb). la lahir dari dan berkembang bersama, dan dijaga oleh masyarakat itu sendiri (Saptomo, 2010: 13). Pendapat ahli tersebut menunjukan hubungan yuridis normatif dengan Pasal 18B UUD 1945 yang secara tegas menunjukkan keberadaan masyarakat hukum adat diakui dengan diberlakukan pengakuan bersyarat.

Pengakuan keberadaan masyarakat hukum adat berdasarkan Pasal 18B UUD 1945 menjadi pedoman pengakuan sekaligus bentuk perlindungan hukum atas keberadaan masyarakat hukum adat di Indonesia. Pengakuan yang dimaksud adalah bahwa masyarakat hukum adat diakui dan dilindungi sebagai subjek hukum dan hak-hak tradisionilnya.Secara factual, wujud pengakuan tersebut ditemukan dalam berbagai kegiatan pemerintahan terutama aktivitas yang berkaitan dengan keberadaan masyarakat hukum adat, termasuk hak masyarakat hukum adat dalam pemanfaatan sumber daya alam dalam hal pengelolaan hutan untuk memperoleh manfaat yang optimal dari hutan dan kawasan hutan bagi kesejahteraan masyarakat. Dalam konteks pengeloaan dan pemanfaatan sumber daya alam oleh masyarakat hukum adat tidak terlepas dari peran Negara yang mengatur pengelolaan tersebut sebagaimana diatur dalam Pasal 33 ayat (3) UUD 1945 yang menegaskan kedudukan Negara sebagai Badan Hukum yang mengatur peruntukan dan pengelolaan hutan oleh warga Negara termasuk masyarakat hukum adat.Melalui kewenangan Hak Menguasai Negara ini, maka tujuan yang ingin dicapai adalah sebesar-besarnya untuk kemakmuran rakyat, dalam hal yang lebih kecil yaitu masyarakat hukum adat. Keberadaan Pasal 33 ayat (3) dan Pasal 18B UUD 1945 menegaskan masyarakat hukum adat memiliki kekuasaan wilayah ulayat termasuk hutan adat sebagai bagian dari keberadaan masyarakat hukum adat. Olehnya itu melalui Undang-Undang No. 41 Tahun 1999 tentang kehutanan dan selanjutnya disebut UU Kehutanan diatur tentang hutan adat.

Pasal 1 Ayat (5) mengatur bahwa hutan adat adalah hutan Negara yang berada dalam wilayah masyarakat hukum adat.Dari definisi ini maka hutan adat adalah hutan Negara dimana hutan adat merupakan hutan yang tidak dibebani hak.Permasalahan hukum pun timbul dari pengaturan tersebut dimana keberadaan 
hutan adat sebagai kekayaan materiil yang dimiliki oleh masyarakat hukum adat tidak dapat serta merta dialihkan melalui proses pengkatogorian hutan adat sebagai hutan Negara. Pengakuan hak masyarakat hukum adat atas wilayahnya adat telah dijamin melalui Pasal 18B UUD 1945.Mengkategorikan hutan adat sebagai hutan Negara secara hukum akan membuat hutan adat yang telah dikuasai secara turun temurun menjadi hilang bahkan penguasaannya bukan lagi oleh masyarakat hukum adat tetapi telah secara serta merta dimiliki oleh Negara. Akibat hal ini muncul berbagai konflik hutan baik secara vertikal yang melibatkan masyarakat hukum adat dengan perorangan (masyarakat pada umumnya), masyarakat hukum adat dengan perusahaan, dan bahkan antar masyarakat hukum adat itu sendiri.Pada sisi lain, konflik hutan juga terjadi secara horizontal yang melibatkan masyarakat hukum adat dengan Pemerintah (Pusat dan Daerah).

Dari hasil temuan yang diungkap oleh Konsorsium Pembaruan Agraria disebutkan bahwa pada tahun 2015 total area konflik agraria seluas 400. 430,00 hektar. Jika di Tahun 2014, sektor pembangunan infrastruktur menjadi penyebab tertinggi, maka di tahun 2015 konflik agraria paling banyak terjadi di sektor perkebunan yakni sebanyak 127 konflik (50\%). Selanjutnya konflik di sektor pembangunan infrastruktur menempati posisi kedua terbanyak sebanyak 70 konflik (28\%), lalu di sektor kehutanan 24 konflik (9,60\%), sektor pertambangan 14 $(5,2 \%)$, kemudian lain-lain 9 konflik(4\%), dan sektor pertanian dan sektor pesisir/kelautan di urutan kelima masing-masing sebanyak 4 konflik (2\%)(Konsorsium Pembaruan Agraria, 2015: 4).

Dengan begitu, dalam kurun waktu 11 tahun terakhir, sejak 2004 hingga 2015, terjadi 1772 konflik agraria dengan luasan wilayah konflik seluas $6.942 .381 \mathrm{Ha}$, yang melibatkan 1.085.817 Kepala Keluarga sebagai korban terdampak langsung konflik agraria berkepanjangan. Berdasarkan data ini menunjukan bahwa konflik agraria yang menyumbangkan angka terbesar berada di sektor kehutanan sebesar 24 Konflik $(9,60)$. Konflik kehutanan tersebut merupakan bukti faktual yang berasal dari permasalahan politik hukum agraria yang telah secara serta merta menjadi Hutan Adat sebagai Hutan Negara.Lebih konkrit lagi, eses yang muncul akibat pengaturan tersebut adalah ditemuinya bentuk-bentuk pelanggaran hak asasi manusia terhadap masyarakat hukum adat yaitu(Komnas HAM, 2016: 75):

1. Pengambilalihan secara sewenang-wenang hutan adat/bagian hutan adat melalui penunjukan dan/atau penetapan sebagai kawasan hutan, peruntukan fungsi konservasi dan penerbitan hak-hak pemanfaatannya kepada pihakpihak lain untuk pengusahaan hutan, perkebunan, pertambangan, atau transmigrasi;

2. Pengambilalihan hutan adat/bagian hutan adat tanpa pemberitahuan tujuan dan implikasi penggunaannya dan tanpa persetujuan sepenuhnya masyarakat hukum adat yang bersangkutan;

3. Perilaku diskrimanatif oleh aparat kepolisian, militer, dan pejabat pemerintah terhadap masyarakat hukum adat; 
4. Penangkapan/penahanan tanpa surat perintah penangkapan/penahanan, tanpa pemberitahuan alasan penangkapan/penahanan, dan tanpa kompensasi.

Kedudukan hak masyarakat hukum adat atas hutan adat yang berada dalam kawasan hutan yang diatur dalam UU Kehutanan belum memberikan jaminan perlindungan hukum bagi masyarakat adat atas wilayah ulayatnya. Oleh karena itu, baru-baru ini UU Kehutanan telah diajukakan judicial review ke Mahkamah Konstitusioleh Aliansi Masyarakat Adat Nusantara (AMAN) dan beberapa organisasi masyarakat hukum adat atas pengaturan hutan adat yang dikategorakan sebagai hutan Negara.Maka Mahkamah Konstitusi melalui kewenangannya,melaluiPutusan Mahkamah Konstitusi No. 35/PUU-IX/2011 yang menegaskan bahwa hutan adat bukanlah hutan adat tapi hutan hak yang telah dimiliki oleh masyarakat hukum adat secara turun-temurun sepanjang dapat dibuktikan keberadaannya membawa satu harapan besar bagi masyarakat hukum adat untuk mendapatkan jaminan perlindungan hukum atas hutan adat yang selama ini telah ditetapkan sebagai hutan Negara.

Keberadaan Putusan Mahkamah Konstitusi No. 35/PUU-IX/2011 yang merupakan pengejewantahan pasal 18B UUD 1945 hingga saat ini masih belum jelas bentuk implemetasinya dalam hal pemberian perlindungan hukum masyarakat hukum adat atas hutan adat yang selama ini berada dalam kawasan hutan. Sejumlah peraturan diterbitkan oleh pemerintah pusat yaitu:

1. Surat Edaran Menteri Kehutanan No. SE. 1/Menhut-II/2013. Surat edaran ini menjelaskan kembali amar putusan dan pendapat MK dalam perkara pengujian konstitusional pasal-pasal dalam UU No. 41 tahun 1999 terkait hutan adat dan masyarakat hukum adat. Namun, secara eksplisit SE ini menegaskan bahwa hutan adat itu harus ditetapkan oleh Menteri Kehutanan, dengan syarat keberadaan masyarakat hukum adat terlebih dahulu ditetapkan dengan peraturan daerah (Safitri dan Uliyah, 2014: 8).

2. Peraturan menteri kehutanan No. P. 62/Menhut-II/2013 tentang perubahan atas peraturan menteri kehutanan nomor P. 44/ Menhut-II/2012 tentang pengukuhan kawasan hutan. Dalam peraturan ini disebut dalam pasal 24A bahwa terhadap wilayah masyarakat hukum adat yang berada dalam kawasan hutan sesuai peraturan daerah provinsi atau kabupaten/kota, maka wilayah masyarakat hukum adat dikeluarkan keberadaannya dari kawasan hutan (Pasal 57 ayat (2)). Dengan menyebutkan bahwa wilayah adat yang berada dalam kawasan hutan dikeluarkan dari kawasan hutan maka peraturan menteri ini telah bertentangan dengan Putusan MK 35 (Safitri dan Uliyah, 2014: 9).

3. Surat edaran menteri dalam negeri no. 522/8900/SJ tanggal 20 Desember 2013 tentang pemetaan sosial masyarakat hukum adat. Surat edaran ini mengusulkan definisi baru mengenai tanah ulayatsebagai bidang tanah yang di atasnya terdapat hak ulayat dari suatu masyarakat hukum adat tertentu; tanah ulayat termasuk tanah kerajaan, keratin, maupun kesultanan (sultan 
ground). Surat Edaran Mendagri ini jelas suatu langkah mundur karena memasukkan tanah kerajaan ke dalam kategori tanah ulayat(Safitri dan Uliyah, 2014: 10).

Beberapa ketentuan di atas menunjukan adanya perbedaan cara pandang kementrian atas Putusan MK No. 35 dalam memberikan perlindungan hukum masyarakat hukum adat atas hutan adat. Dari sisi substansi hukum, ketentuanketentuan tersebut mengatur prosedur yang berbeda-beda dalam memberikan pengakuan, perlindungan hak masyarakat hukum adat atas hutan adat. Implementasi putusan MK No. 35 melalui sejumlah aturan tersebut dianggap bias dan mendatangkan ketidakpastian hukum dan belum tercapainya perlindungan hukum masyarakat hukum adat atas hutan adat.

Peraturan perundang-undangan nasional lain juga memerintahkan pengaturan dan penetapan masyarakat hukum adat melalui produk hukum daerah. UU No. 23 tahun 2014 tentang pemerintahan daerah, misalnya memberikan mandat kepada pemerintah provinsi dan kabupaten/kota untuk menerbitkan surat keputusan kepala daerah tentang pengakuan, perlindungan masyarakat hukum adat dan wilayahnya.

Melalui permendagri No. 52 tahun 2014 tentang pengakuan, perlindungan masyarakat hukum adat, peran pemerintah daerah dalam memberikan pengakuan, perlindungan menjadi lebih konkrit dengan diterbitkannya surat keputusan kepala daerah tentang masyarakat hukum adat dan wilayahnya (hutan adat).

Jelas, pemerintah daerah menjadi ujung tombak penting implementasi putusan MK 35.Namun demikian, banyak pemerintah daerah ragu terhadap kewenangan ini.Sementara sejumlah peraturan daerah yang ada di berbagai kabupaten pada umumnya bersifat pengaturan dan bukan penetapan terhadap masyarakat hukum adat dan wilayahnya.Padahal, KLHK berdasarkan UU No. 41 tahun 1999 meminta adanya peraturan daerah yang bersifat penetapan sebagai syarat pengakuan hutan adat.Maka melalui putusan MK No. 35 dengan mandat yang dimiliki oleh pemerintah daerah dianggap dapat mewujudkan perlindungan hukum bagi pemenuhan hak masyarakat hukum adat atas hutan adat. Namun dalam perjalananannya Putusan MK No. 35 dan Permendagri No. 52 tahun 2014 hingga saat ini masih belum efektif diterapkan dalam memberikan kepastian hukum atas status hukum masyarakat hukum adat dan wilayahnya (hutan adat). Karena ituberdasarkan permasalahan tersebut maka yang menjadi fokus dalam penelitian ini adalah:

a. Bagaimana prinsip-prinsip pengaturan Hutan Adat berdasarkan Putusan Mahkamah Konstitusi No. 35/PUU-IX/2011?

b. Bagaimana peran pemerintah daerah dalam mewujudkan Perlindungan Hukum Masyarakat Hukum Adat pasca Putusan Mahkamah Konstitusi No. 35/PUU-IX/2011? 


\section{B. METODE PENELITIAN}

Penelitian ini merupakan penelitian hukum normatif (normative legal research) yakni penelitian hukum yang dilakukan dengan cara meneliti dan menelaah peraturan perundang-undangan.

Pendekatan penelitian yang digunakan dalam penelitian ini ada 2 (dua) yaitu pendekatan undang-undang (statute approach) dan pendekatan konseptual (conceptual approach). Pendekatan undang-undang (statute approach) dilakukan dengan menelaah semua undang-undang dan regulasi yang bersangkut-paut dengan isu hukum yang sedang ditangani.Pendekatan konseptual beranjak dari pandanganpandangan dan doktrin-doktrin yang berkembang di dalam ilmu hukum. Dengan mempelajari pandangan-pandangan dan doktrin-doktrin di dalam ilmu hukum, peneliti akan menemukan ide-ide yang melahirkan pengertian-pengertian hukum, konsep-konsep hukum, dan asas-asas hukum yang relevan dengan isu yang dihadapi (Marzuki, 2010: 93).

Bahan hukum primer yang digunakan oleh peneliti dalam penelitian ini yaitu, Undang-Undang Dasar Negara Republik Indonesia Tahun 1945, Tap MPR No. IX/MPR/2001, Undang-Undang No. 5 Tahun 1960 tentang Peraturan Dasar Pokok Agraria, Undang-Undang No. 41 Tahun 1999 tentang Kehutanan, Putusan Mahkamah Konstitusi No. 35/PUU-X/2012 serta undang-undang dan peraturanperaturan lainnya yang berkaitan dengan isu penelitian. Bahan hukum sekunder yang digunakan adalah buku, hasil penelitian, jurnal hukum, surat kabar, media internet, makalah dan sumber-sumber lainnya yang terkait dengan masalah kehutanan.

Data diperoleh peneliti melalui penelusuran bahan-bahan hukum. Untuk pendekatan perundang-undangan, peneliti mencari perundang-undangan terkait dengan masyarakat hukum adat baik yang bersifat regulation bahkan juga delegated legislation dan delegated regulation. Sedangkan untuk pendekatan konsep peneliti mengumpulkan dengan cara melakukan penelusuran buku-buku hukum (treatises) dalam hal ini yaitu Buku Komnas Ham I, II, III, IV yang membahas mengenai Hak Asasi Masyarakat Hukum Adat (Marzuki, 2010: 237-239).

Bahan-bahan hukum tersebut kemudian diteliti menggunakan pendekatan yang ada untuk menjawab isu hukum yang selanjutnya memberikan preskripsi tentang legal solution (solusi hukum)atas isu hukum yang dibahas.

\section{PEMBAHASAN}

1. Prinsip-Prinsip Pengaturan Hutan Adat berdasarkan Putusan Mahkamah Konstitusi No. 35/PUU-IX/2011

Putusan MK No. 35 /PUU-X/2012 adalah putusan Mahkamah Konstitusi atas permohonan uji materiil terhadap UU No. 41 Tahun 1999 tentang Kehutanan. Permohonan uji materiil ini diajukan oleh 3 pemohon bersama-sama, yakni Aliansi Masyarakat Adat Nusantara (AMAN), Kesatuan Masyarakat Hukum Adat Kenegerian Kuntu (Kabupaten Kampar Provinsi Riau), dan Kesatuan Masyarakat Hukum Adat Kesepuhan Cisitu (Kabupaten Lebak Provinsi Banten). 
Melalui Putusan No. 35 /PUU-X/2012 ini, MK menganulir beberapa pasal yang ada di dalam UU No. 41 Tahun 1999 tentang Kehutanan, yakni pasal 1 angka 6, pasal 4 ayat 3 , pasal 5 ayat 1 , dan pasal 5 ayat 2 .

Perubahan pada pasal-pasal yang dianulir tersebut adalah sebagai berikut:

a. Pasal 1 angka 6 menjadi berbunyi:

"Hutan adat adalah hutan yang berada dalam wilayah masyarakat hukum adat."

b. Pasal 4 ayat 3 menjadi berbunyi:

"Penguasaan hutan oleh negara tetap memperhatikan hak masyarakat hukum adat, sepanjang masih hidup dan sesuai dengan perkembangan masyarakat dan prinsip Negara Kesatuan Republik Indonesia yang diatur oleh undang-undang."

c. Pasal 5 ayat 1 menjadi berbunyi:15

"Hutan negara sebagaimana dimaksud pada ayat (1) huruf a, tidak termasuk hutan adat."

d. Pasal 5 ayat 2 menjadi tidak berlaku.

e. Pasal 5 ayat 3 menjadi berbunyi:

"Pemerintah menetapkan status hutan sebagaimana dimaksud pada ayat (1); dan hutan adat ditetapkan sepanjang menurut kenyataannya masyarakat hukum adat yang bersangkutan masih ada dan diakui keberadaannya."

Merujuk pada putusan MK No. 35/PUU-X/2012 di atas, maka kita bisa membandingkankonsep pengaturan mengenai hutan adat sebelum dan sesudah keluarnya putusan MK ini.Sebelum adanya putusan MK No. 35/PUU-X/2012, prinsip pengaturan UU No. 41 Tahun 1999 adalah: Pertama, terdapat 2 (dua) jenis hutan, yakni hutan negara dan hutan hak, dimana hutan hak adalah hutan yang berada pada tanah yang dibebani hak atas tanah (vide: Pasal 1 angka 5 UU No. 41 Tahun 1999), sedangkan hutan negara adalah hutan yang berada pada tanah yang tidak dibebani hak atas tanah (vide: Pasal 1 angka 4 UU No. 41 Tahun 1999). Kedua, yang disebut sebagai "hutan adat" adalah hutan negara yang berada di dalam wilayah masyarakat hukum adat (vide: Pasal 1 angka 5 UU No. 41 Tahun 1999 pra putusan MK No. 35/PUU-X/2012). Sehingga, walaupun eksistensi hutan adat sebagai hutanyang terkait dengan eksistensi masyarakat hukum adat diatur oleh UU No. 41 Tahun 1999, hutan adat sesungguhnya adalah hutan negara dan oleh karenanya, walaupun istilahnya disebut sebagai "hutan adat", masyarakat hukum adat sesungguhnya tidak memiliki kekuasaan secara penuh atas jenis hutan ini.Melalui putusan MK No. 35/PUU-X/2012, prinsip-prinsip di atas telah dirubah secara cukup radikal. Sehingga, prinsip pengaturan dalam UU No. 41 Tahun 1999 menyangkut eksistensi hutan adat menjadi sebagai berikut:

a. Pertama, apa yang disebut sebagai "hutan adat" sekarang menjadi terpisah dari hutannegara. Hal ini merujuk pada pendapat MK yang menyatakan bahwa sesuai denganpengaturan dalam pasal 18B ayat (2) UUD 1945, kesatuan masyarakat hukum adat adalahsuatu subyek hukum yang 
memiliki kapasitas untuk menyandang hak (dan kewajiban), danoleh karenanya masyarakat hukum adat sudah seharusnya memliki hak atas hutan(Putusan MK No. 35/PUU-X/2012).

b. Kedua, karena UU No. 41 Tahun 1999 hanya mengenal 2 (dua) jenis hutan yakni hutannegara dan hutan hak, mendasarkan pada prinsip pertama di atas bahwa kesatuanmasyarakat hukum adat seharusnya juga memiliki hak atas hutan, maka merujuk padapendapat MK, apa yang disebut sebagai hutan adat adalah bagian dari hutan hak danbukan bagian dari hutan negara(Putusan MK No. 35/PUU-X/2012, H. 173, 179, 181).

c. Ketiga, apa yang disebut sebagai "hutan adat" pasca adanya putusan MK No. 35/PUUX/2012 ini menjadi didefinisikan sebagai "hutan yang berada dalam wilayah masyarakathukum adat" (Putusan MK No. 35/PUU-X/2012, H. 185).

d. Keempat, hutan adat sebagai hutan yang haknya dipunyai suatu kesatuan masyarakathukum adat akan diakui jika keberadaan kesatuan masyarakat hukum adat tersebut diakui,dan untuk dapatnya suatu kesatuan masyarakat hukum adat diakui keberadaannya, ia harusmemenuhi syarat pengakuan sebagaimana diatur oleh UUD 1945, yakni masyarakat hukumadat tersebut senyatanya masih hidup dan sesuai dengan perkembangan masyarakat danprinsip Negara Kesatuan Republik Indonesia (Putusan MK No. 35/PUU-X/2012, H. 185-186). Hal ini mengubah prinsip yang adasebelumnya, dimana untuk supaya dapat diakui, suatu kesatuan masyarakat hukum adatharus memenuhi syarat yang salah satunya adalah tidak boleh bertentangan dengan kepentingannasional.Merujuk pada prinsip-prinsip pengaturan yang baru menyangkut hutan adat pasca adanyaputusan MK No. 35/PUU-X/2012 sebagaimana di atas, dapat diketahui bahwa kini telahdikukuhkan masyarakat hukum adat memiliki hak atas hutan, yang kemudian disebutsebagai hutan adat. Sehingga, hak masyarakat hukum adat atas hutan ini secara tegas telahdiakui keberadaanya oleh UU No. 41 Tahun 1999 pasca putusan MK No. 35/PUU-X/2012.

Supaya suatu kesatuan masyarakat hukum adat dapat menikmati hak atashutan ini, terdapat persyaratan yang harus dipenuhi oleh kesatuan masyarakat hukum adattersebut, yakni bahwa keberadaan masyarakat hukum adat yang bersangkutan harus telahdiakui terlebih dahulu dulu.UU No. 41 Tahun 1999 melalui penjelasan pasal 67 ayat (1) mengatur tentang unsur-unsuryang harus dipenuhi agar sebuah kesatuan masyarakat hukum adat dapat diakuikeberadaannya, yakni:

a. Masyarakatnya masih dalam bentuk paguyuban (rechtsgemeenschap).

b. Ada kelembagaan dalam bentuk perangkat penguasa adatnya.

c. Ada wilayah hukum adat yang jelas.

d. Ada pranata dan perangkat hukum, khususnya peradilan adat, yang masihditaati. 
e. Masih mengadakan pemungutan hasil hutan di wilayah hutan sekitarnya untukpemenuhan kebutuhan hidup sehari-hari.

Berkaitan dengan syarat-syarat pengakuan keberadaan suatu kesatuan masyarakat hukum adat, maka perlu juga dirujuk syarat-syarat tersebut sebagaimana yang diatur dalam pasal 18B ayat 2 UUD 1945, yang jika didasarkan pada pendapat MK sebagaimana yang tertuang dalam putusan MK No. 31/PUUV/2007 dan Putusan MK No. 35/PUU-X/2012, syarat-syarat tersebut dapat dijabarkan menjadi 10 unsur kumulatif, yakni (Kurniawan, Arianto, dan Widowati, 2014: 22):

a. Kesatuan masyarakat hukum adat yang bersangkutan adalah kesatuanmasyarakat hukum adat yang eksistensinya telah ada sejak jaman nenek moyangdan berhasil mempertahankan eksistensinya tersebut hingga kini tanpaterputus;

b. Warga anggotanya memiliki perasaan kelompok (in-group feeling);

c. Memiliki pranata pemerintahan adat;

d. Memiliki harta kekayaan dan/atau benda-benda adat;

e. Memiliki perangkat norma hukum adat;

f. Khusus untuk kesatuan masyarakat hukum adat berjenis teritorial, memilikiwilayah tertentu.

g. Substansi hak-hak tradisional dari kesatuan masyarakat hukum adat tersebutdiakui dan dihormati oleh warga kesatuan masyarakat yang bersangkutanmaupun masyarakat yang lebih luas, serta tidak bertentangan dengan hak-hakasasi manusia.

h. Keberadaannya tidak mengancam kedaulatan dan integritas NKRI.

i. Substansi norma hukum adatnya sesuai dan tidak bertentangan denganperaturan perundang-undangan.

j. Keberadaan kesatuan masyarakat hukum adat beserta hak-hak tradisionalnyatersebut telah diakui berdasarkan UU ataupun Peraturan Daerah (Perda).

Berdasarkan kesepuluh syarat di atas, maka dapat dikatakan bahwa syaratsyarat yang ada dalam Penjelasan Pasal 67 ayat (1) UU No. 41 Tahun 1999 khususnya unsur nomor 1 hingga nomor 4 dapat dikatakan juga tercakup dalam ke10 unsur dalam pasal 18B ayat 2 UUD 945 yang dipaparkan oleh MK dalam putusannya No. 31/PUU-V/2007 dan putusan No. 35/PUU-X/2012 sebagaimana dijabarkan di atas. Sehingga, bisa dikatakan bahwa syarat agar suatu kesatuan masyarakat hukum adat dapat diakui keberadaannya terkait dengan hak masyarakat hukum adat atas hutan, maka kesatuan masyarakat hukum adat tersebut harus memenuhi secara kumulatif kesepuluh syarat tersebut di atas ditambah satu syarat sebagaimana diatur dalam poin ke-5 di Penjelasan Pasal 67 ayat (1) UU No. 41 Tahun 1999. Sehingga jika digabung secara keseluruhan, unsurunsur yang berfungsi sebagai syarat pengakuan keberadaan suatu kesatuan masyarakat hukum adat terkait dengan hak mereka atas hutan adat adalah: 
a. Kesatuan masyarakat hukum adat yang eksistensinya telah ada sejak jaman nenek moyang dan berhasil mempertahankan eksistensinya tersebut hingga kinitanpa terputus;

b. Warga anggotanya memiliki perasaan kelompok (in-group feeling);

c. Memiliki pranata pemerintahan adat;

d. Memiliki harta kekayaan dan/atau benda-benda adat;

e. Memiliki perangkat norma hukum adat;

f. Khusus untuk kesatuan masyarakat hukum adat berjenis teritorial, memilikiwilayah tertentu;

g. Substansi hak-hak tradisional dari kesatuan masyarakat hukum adat tersebut diakui dan dihormati oleh warga kesatuan masyarakat yang bersangkutan maupun masyarakat yang lebih luas, serta tidak bertentangan dengan hak-hakasasi manusia;

h. Keberadaannya tidak mengancam kedaulatan dan integritas NKRI;

i. Substansi norma hukum adatnya sesuai dan tidak bertentangan dengan peraturan perundang-undangan;

j. Keberadaan kesatuan masyarakat hukum adat tersebut diakui berdasarkan UU ataupun Perda, dan;

k. Masih mengadakan pemungutan hasil hutan di wilayah hutan sekitarnya untukpemenuhan kebutuhan hidup sehari-hari.

Berdasarkan seluruh penjabaran di atas, ada beberapa poin penting yang bisa diambil terkait hak masyarakat hukum adat atas hutan sebagaimana yang diatur dalam Putusan MKNo. 35/PUU-X/2012. Poin-poin penting tersebut adalah sebagai berikut:

a. Pertama, putusan MK No. 35/PUU-X/2012 adalah sebuah putusan yang memberikan konsepbaru menyangkut hak masyarakat hukum adat atas sumber daya alam, dalam hal ini hak atas hutan. Konsep baru tersebut mengatur bahwa hak masyarakat hukum adat atas sumber daya alam berupa hutan yang disebut sebagai hutan adat adalah hak yang dikuasai secara penuh oleh kesatuan masyarakat hukum adat, sebagaimana penguasaansubyek hukum yang lain (individu atau badan hukum di luar masyarakat hukum adat) atasjenis hutan hak yang lain. Secara normatif, hal ini mengakibatkan tidak dimungkinkannya lagi adanya intervensi dan atau pengambil alihan hutan adat secara sepihak oleh Negara dengan kliam bahwa hutan adat tersebut sejatinya adalah hutan negara.

b. Kedua, walaupun telah terbangun suatu konsep baru tentang hak masyarakat hukum adatatas hutan yang bersifat penuh yang bernama hutan adat, hal ini tidak serta merta membuat suatu kesatuan masyarakat hukum adat secara otomatis memiliki kewenangan untuk mendapatkan hak tersebut. Sesuai dengan isi Putusan MK No. 35/PUU-X/2012 jo.Putusan MK No. 31/PUU-V/2007 serta Penjelasan Pasal 67 UU No. 41 Tahun 1999, diatur mengenai syarat-syarat diakuinya suatu eksistensi kesatuan masyarakat hukum adat di mana hal ini adalah prasyarat dapat 
diberikannya suatu hak atas hutan kepada masyarakat hukum adat tersebut. Dengan kata lain, suatu hak atas hutan hanya dapat diberikan kepadasuatu kesatuan masyarakat hukum adat yang sebelumnya sudah diakui eksistensinya terlebih dahulu. Jika ada suatu kesatuan masyarakat hukum adat tidak dapat diakui keberadaannya dikarenakan gagal memenuhi kesebelas unsur prasyarat pengakuan eksistensi masyarakat hukum adat menurut putusan MK dan UU No. 41 Tahun 1999 sebagaimana telah dijabarkan di atas, maka tentu hak atas hutan tidak dapat diberikankepada kesatuan masyarakat hukum adat tersebut (Pasal 67 ayat (2) jo. Penjelasan Pasal 67 ayat (2) UU No. 41 tahun 1999).

Adanya prasyarat sebagaimana di atas tentu akan menjadi sebuah kesulitan tersendiri bagisuatu kesatuan masyarakat hukum adat untuk mendapatkan hak mereka atas hutan. Hal ini dikarenakan akan sangat sedikit kesatuan masyarakat hukum adat yang dapat memenuhi kesebelas unsur prasyarat tersebut. Semisal mengenai unsur prasyarat nomor 1, yakni bahwa kesatuan masyarakat hukum adat yang bersangkutan eksistensinya harus sudah ada sejak jaman dahulu dan berhasil tetap dipertahankan tanpa terputus hingga saat ini. Hal ini tentu saja cukup sulit untuk dipenuhi, dan kalaupun ada jumlahnya akan sangat sedikit. Hal ini mengingat adanya kebijakan semasa Orde Baru di masa lalu selama 32 tahun yang banyak mencerabut hak-hak masyarakat hukum adat, serta penerapan kebijakan-kebijakan yang serba sentralistis danotokratis yang ditunjang dengan penerapan sistem pemerintahan administratif yang serba diseragamkan mulai dari tingkat pusat hingga tingkat paling bawah di daerah, sehingga banyak membuat eksistensi kesatuan masyarakat hukum adat menjadi tertekan lalu kemudian hilang.

\section{Peran Pemerintah Daerah Dalam Mewujudkan perlindungan hukum masyarakat hukum adat atas hutan adat pasca Putusan Mahkamah Konstitusi No. 35/PUU-IX/2011.}

Sesuai amanat pasal 18B UUD 1945 bahwa keberadaan masyarakat hukum adat diakui dengan prasyarat yaitu sepanjang masih hidup dan sesuai dengan perkembangan masyarakat. Pengakuan bersyarat oleh UUD 1945 menunjukan bahwa oleh hukum nasional indonesia keberadaan masyarakat hukum adat diakui dan dilindungi. secara filosofis pengakuan dan penghormatan Negara terhadap masyarakat hukum adat mencakup 3 (tiga) hal yaitu: keberadaan masyarakat hukum adat, keberadaan lembaga/institusi yang ada dalam masyarakat hukum adat dan keberadaan aturan/norma hukum adat dalam kehidupan masyarakat hukum adat. Bentuk pengakuan dan penghormatan Negara terhadap masyarakat hukum adat di indonesia dapat ditelusuri dari ketentuan-ketentuan yang ada dalam UUD 1945, Ketetapan MPR, Undang-Undang, dan Peraturan Pemerintah.

Secara filosofis, pengakuan dan penghormatan terhadap masyarakat hukum adat juga mengandung makna bahwa Negara juga harus mengakui dan menghormati keberadaan masyarakat hukum adat. Hukum adat yang ada, hidup, tumbuh, dan berkembang di Indonesia bersifat luwes, fleksibel dan sesuai dengan nilai-nilai Pancasila. Pembukaan UUD 1945 memuat pokok-pokok pikiran yang 
menjiwai sistem hukum nasional yang terdiri atas unsure hukum tertulis, hukum tidak tertulis (hukum adat) dan hukum agama. Hukum adat sebagai wujud kebudayaan rakyat indonesia menjelmakan perasaan hukum yang nyata dan hidup di kalangan rakyat dan mencerminkan kepribadian masyarakat dan bangsa Indonesia (Sulastriyono, 2014: 46)

Secara filosofis, pengakuan dan penghormatan tersebut merupakan penghargaan dari Negara terhadap nilai-nilai kemanusiaan dan hak asasi manusia, nilai kebersamaan dan nilai keadilan. Secara yuridis, ketentuan tersebut memberikan landasan konstitusional bagi arah politik hukum pengakuan dan penghormatan hak-hak tradisional masyarakat hukum adat atas hak sumber daya alam.Hubungan antara masyarakat adat dengan sumberdaya alamnya atau hak ulayat merupakan kondisi konstitutif bagi eksistensi masyarakat adat. Hubungan antara masyarakat dengan tanah atau sumberdaya alamnya merupakan inti dari konsep ulayat.Konsep ulayat lahir dari hak alamiah (natural rights), kemudian dalam negara modern atau negara demokratis konstitusional, ulayat sebagai natural rights itu dikonversi menjadi natural law di dalam hukum positif. Tidak semua negara yang mengadopsi konsep ulayat di dalam hukum positifnya. Adopsi ulayat sebagai hak dalam hukum positif merupakan suatu upaya mendamaikan antara hukum modern yang dipakai untuk menata kehidupan (secondary rules) dengan hukum asli yang ada di dalam komunitas masyarakat (primary rules) (Saleo, 2014: 94).

Putusan MK No. 35 tahun 2002 menegaskan dua aspek penting bagi masyarakat hukum adat yaitu Pertama, menyatakan bahwa hutan adat bukan lagi hutan Negara, dalam putusan MK menyebutkan bahwa hutan adat adalah hutan yang berada dalam wilayah adat milik masyarakat adat. Putusan MK 35 merupakan sebuah terobosan hukum yang dilakukan oleh hakim MK untuk memberikan pengakuan masyarakat adat dan wilayah adatnya karena putusan ini semakin menegaskan bahwa masyarakat hukum adat adalah subjek hukum dan pemilik hak atas wilayah adat.Kedua, Mahkamah Konstitusi telah mengabulkan permohonan pencabutna pasal 67 UU Kehutanan kembali menegaskan pengakuan bersyarat bagi masyarakat adat. Mahkamah konstitusi berpandangan pengakuan keberadaan masyarakat adat melalui perda masih relevan dan tidak inkonstitusional sepanjang belum adanya undang-undang masyarakat adat (Arman, 2016: 4).

Dengan demikian pengakuan bersyarat keberadaan masyarakat adat melalui perda sebagaimana dimandatkan undang-undang kehutanan masih tetap berlaku.Mahkamah konstitusi sepertinya lupa mempertimbangkan bahwa realitas politik local pengakuan melalui perda sangat berat dan memerlukan biaya politik yang tidak muruh. Pengakuan hukum mestinya cukup melalui keputusan kepala daerah provinsi/kabupaten/kota. Dari data yang dirilis oleh Epistema Institute pada bulan agustus 2015 menyebutkan bahwa terdapat 124 produk hukum daerah terkait masyarakat dengan materi muatan meliputi pengaturan mengenai lembaga adat dan peradilan adat, keberadaan masyarakat adat, desa adat, wilayah, tanah, hutan, dan sumber daya alam lainnya. Dari data tersebut baru 15.577 hektar 
wilayah, tanah dan hutan adat yang telah ditetapkan melalui produk hukum daerah. Dalam catatan aliansi masyarakat adat nusantara (AMAN) tahun 2015-2016 hanya 21 (dua puluh satu) kabupaten/kota dan 3 (tiga) Provinsi yang memasukkan rancangan perda masyarakat adat sebagai program legislasi daerahnya (Arman, 2016: 5).

Data-data tersebut di atas menunjukan bahwa rute pengakuan masyarakat adat melalui perda bukanlah hal yang mudah. Faktor-faktor yang mempengaruhiu rendahnya perda pengakuan masyarakat adat di daerah disebabkan masih minimnya keinginan politik pemerintah daerah untuk mengakui keberadaan masyarakat adat dan menganggap bahwa pengakuan masyarakat adat belum menjadi hal yang urgent dan prioritas. Faktor lain juga seringkali timbul dari adanya tarik menarik kepentingan antara korporasi dengan pemerintah daerah dan masyarakat adat. Ada "kekhawatiran" dengan diakuinya masyarakat adat akan meningkatkan perlawanan masyarakat adat kepada perusahaan kepada perusahaan yang berada di atas wilayah adat, sehingga dianggap akan menyebabkan terhambatnya iklim investasi di daerah. Disisi lain desakan dari gerakan masyarakat adat masih melakukan advokasi pengakuan masyarakat adat melalui perda. Sebagian masyarakat adat masih kurang terorganisis dengan baik dalam memperjuangkan perda. Dari segi proses, pembahasan rancangan perda membutuhkan waktu yang cukup lama. Dari mulai proses advokasi mengusulkan masuk ke prolegda, penyusunan dan pembahasan hingga pengesahan rancangan perda menjadi perda memerlukan waktu sekurang-kurangnya 2 (dua) tahun. Jika dibandingkan dengan pengakuan melalui keputusan kepala daerah, penetapan masyarakat adat relative muda karena cukup berhubungan dengan satu pintu yaitu pemerintah.Dalam catatan AMAN, pada tahun 2015 telah terbit 11 (sebelas) keputusan kepala daerah penetapan masyarakat adat (Arman, 2016: 6).

Dalam hal dari itu maka melalui Putusan Mahkamah Konstitusi No. 35/PUUIX/2011 maka bentuk prelindungan hukum masyarakat hukum adat atas hutan adat yang berada dalam kawasan hutan adalah:

a. Melanjutkan inventarisasi perda terkait masyarakat hukum adat;

b. Mempercepat penyelesaian RUU tentang pengakuan dan perlindungan masyarakat hukum adat (inisiatif DPR) yang dalam hal ini kementrian kehutanan telah ditunjuk sebagai coordinator penyiapan RUU dimaksud;

c. Telah dibentuk tim kerja penyusunan rancangan undang-undang tentang pengakuan dan perlindungan hak masyarakat hukum adat dengan SK Menteri Kehutanan No. SK. 3201/Menhut-II/Kum/2013 tanggal 18 juni 2013;

d. Membentuk tim sosialisasi Putusan Mahkamah Konstitusi No. 35/PUUIX/2011 dengan SK Sekretaris Jenderal No. SK.167/II-Kum/2013 tanggal 15 Juli 2013.

e. Menerbitkan surat edaran menteri kehutanan No. SE. 1/Menhut-II/2013 tanggal 16 Juli 2013 kepada gubernur/Bupati/Walikota seluruh Indonesia 
dan Kepala Dinas Provinsi/kabupaten/kota yang membidangi kehutanan yang memuat penjelasan putusan MK

f. Mempercepat lahirnya putusan pemerintah tentang pengelolaan hutan adat sebagai pelaksanaan dari Undang-Undang No. 41 tahun 1999

g. Telah berkoordinasi dengan kemendagri untuk mendorong Pemda segera mendata, melakukan penelitian dan mengukuhkan keberadaan masyarakat hukum adat beserta wilayah adatnya.

h. Apabila terbukti terdapat wilayah masyarakat hukum adat yang berdasarkan perda berada dalam kawasan hutan dikeluarkan dari kawasan hutan.

Upaya pengimplementasian Putusan MK No. 35 dapat ditempuh dengan memanfaatkan sejumlah peraturan perundang-undangan yang memberi pengakuan dan perlindungan terhadap masyarakat hukum adat.

Peraturan Menteri Dalam Negeri No.1 tahun 2014 Tentang Pembentukan Produk Hukum Daerah menyatakan bahwa produk hukum daerah itu meliputi peraturan daerah atau nama lainnya, peraturan kepala daerah, peraturan bersama kepala daerah, peraturan DPRD dan peraturan yang berbentuk keputusan meliputi keputusan kepala daerah, keputusan DPRD, Keputusan Pimpinan DPRD, dan keputusan badan kehormatan DPRD.

Produk hukum daerah ada yang bersifat pengaturan dan ada yang bersifat penetapan. Produk hukum yang bersifat pengaturan memberikan aturan yang berlaku umum terhadap suatu bidang. Permendagri No. 1 Tahun 2014 memberikan contoh produk hukum daerah yang bersifat pengaturan adalah peraturan daerah atau peraturan daerah khusus, peraturan kepala daerah (peraturan gubernur atau peraturan bupati/walikota) peraturan bersama kepala daerah (peraturan bersama gubernur atau peraturan bersama bupati/walikota) atau peraturan DPRD. Sementara itu produk hukum daerah yang bersifat penetapan adalah produk hukum yang bersifat konkrit, individual, final dan berakibat hukum pada seseorang atau badan hukum perdata. Termasuk ke dalam kategori penetapan ini adalah keputusan kepala daerah (Keputusan gubernur atau keputusan bupati/walikota), keputusan DPRD, keputusan pimpinan DPRD, dan keputusan Badan Kehormatan DPRD (Safitri, 2014: 69).

Sejumlah bentuk produk hukum daerah tersebut dapat dijadikan kerangka hukum untuk mengimplementasikan Putusan MK No. 35 baik dalam bentuk Peraturan Daerah dan/atau Keputusan Kepala Daerah. Salah satu peraturan tersebut adalah Peraturan Menteri dalam Negeri No. 52 tahun 2014 tentang pedoman pengakuan dan perlindungan hukum masyarakat hukum adat dan selanjutnya disebut Permendagri No. 52 tahun 2014 yang mengatur pengakuan dan perlindungan hukum masyarakat adat dalam bentuk surat keputusan kepala daerah. Peraturan ini telah mengakomodir Putusan MK No. 35 dan secara jelas mengatur mengenai keberadaan masyarakat hukum adat dan wilayah adat. Pengakuan dan Perlindungan masyarakat hukum adat oleh Permendagri No. 52 tahun 2014 dibuat dalam bentuk Peraturan Daerah ataupun keputusan Kepala Daerah. 
Prosedur pengakuan dan perlindungan hukum atas keberadaan masyarakat hukum adat dimulai dari Bupati/Walikota membentuk Panitia Masyarakat Hukum Adat yang kemudian dari Panitia akan melalukan tahapan yaitu: a) identifikasi masyarakat hukum adat; b) verifikasi dan validasi masyarakat hukum adat, dan; c) penetapan masyarakat hukum adat. Setelah terbentuk Panitia Masyarakat hukum adat maka tahap awal yang dilakukan adalah melakukan identifikasi masyarakat hukum adat dengan mempertimbangkan hal-hal sebagai berikut:

a. Sejarah masyarakat hukum adat

b. Wilayah adat

c. Hukum adat

d. Harta kekayaan dan/atau benda-benda adat

e. Kelembagaan/sistem pemerintahan adat.

Poin-poin pertimbangan tersebut diatas yang hasilnya nanti akan divalidasi dan diverivikasi selama jangka waktu 1 (satu) bulan. Hasil verifikasi Panitia Masyarakat hukum adat ini kemudian akan disampaikan dalam bentuk rekomendasi kepada Bupati/Walikota untuk kemudian ditetapkan dalam bentuk keputusan kepala daerah. Surat Keputusan Kepala Daerah tentang Pengakuan dan Perlindungan Hukum Masyarakat Hukum Adat nantinya menjadi landasan hukum bagi masyarakat hukum untuk mengatur wilayah adat termasuk hutan adat. Terbitnya surat keputusan kepala daerah ini juga akan mengatur kewilayahan adat termasuk hutan adat yang telah dikuasai secara turun temurun oleh masyarakat adat dengan pengaturan batas-batas yang jelas dari wilayah adat tersebut.

Berdasarkan hal tersebut di atas maka bentuk konkrit pengimplementasian Putusan MK No. 35 dalam menjamin kepastian hukum atas penguasaan hutan adat oleh masyarakat hukum adat adalah dengan menghasilkan produk hukum daerah dalam bentuk suratkeputusan kepala daerah tentang pengakuan dan perlindungan masyarakat hukum adat.

\section{KESIMPULAN DAN SARAN}

\section{Kesimpulan}

Prinsip-Prinsip Pengaturan Hutan Adat berdasarkan Putusan Mahkamah Konstitusi No. 35/PUU-IX/2011 adalah a) Hutan adat terpisah dari Hutan Negara; b) Hutan adat merupakan hutan hak; c) Definisi Hutan adat adalah hutan yang berada dalam wilayah masyarakat hukum adat, dan; d) hutan adat merupakan hak yang dimiliki oleh masyarakat hukum adat. Sedangkan peran pemerintah daerah dalam mewujudkan perlindungan hukum masyarakat hukum adat atas hutan adat pasca Putusan Mahkamah Konstitusi No. 35/PUU-IX/2011 adalah dengan menerbitkan surat keputusan kepala daerah tentang pengakuan, perlindungan masyarakat hukum adat dan wilayahnya termasuk didalamnya hutan adat.

\section{Saran}

Pemerintah Daerah (Provinsi, Kabupaten/Kota) perlu melakukan sosialisasi Putusan Mahkamah Konstitusi No. 35/PUU-IX/2011 kepada masyarakat khususnya masyarakat hukum adat. Selain itu pemerintah pusat dan pemerintah daerah segera 
membentuk Panitia Masyarakat Hukum Adat baik di tingkat Pusat, Daerah (Kabupaten/Kota) untuk mengidentifikasi berdasarkan permohonan dari masyarakat hukum adat untuk kemudian rekomendasi diberikan kepada Bupati/Walikota untuk diterbitkan Surat keputusan kepala daerah tentang pengakuan,perlindungan masyarakat hukum adat beserta wilayahnya termasuk hutan adat.

\section{DAFTAR PUSTAKA}

Arman, Muhammad (2016). "Legislasi Daerah Masyarakat Adat Pasca Putusan MK. 35/PUU-X/2012". Makalah pada pertemuan Simposium Masyarakat Adat II Gerakan Masyaraakt Adat dan Pembaharuan Hukum Peringatan 2 tahun Putusan Mahkamah Konstitusi No. 35/PUU-X/2012. Universitas Pancasila.

Kurniawan, Joeni Arianto (2016). "Kedudukan Hak Masyarakat Hukum Adat Atas Sumber Daya Alam". Makalah Pada Pertemuan Simposium Masyarakat II Gerakan Masyarakat Adat dan Pembaruan Hukum. Jakarta.

Nugroho, Bambang Daru 2015. Hukum Adat Hak Menguasai Negara Atas Sumber Daya Alam Kehutanan \& Perlindungan Terhadap Masyarakat Hukum Adat. Bandung. PT Reflika Aditama.

Safitri, Myrna A. dan Uliyah, Luluk (2014). Adat di tangan Pemerintah Daerah Panduan Penyusunan Produk Hukum Daerah Untuk Pengakuan dan Perlindungan Hak Asasi Manusia. Jakarta. Epistema Institute.

Saleo, Admon (2014). Pengakuan Masyarakat adat Tentang Hak Ulayat. Jurnal Lex Privatum, Vol II, No. 1.

Saptomo, Ade (2010). Hukum \& Kearifan Lokal-Revitalisasi Hukum Adat Nusantara. Jakarta: Grasindo.

Simarmata, Rikardo (2006). Pengakuan Hukum Terhadap Masyarakat Adat di Indonesia. Jakarta: UNDP Regional Centre in Bangkok.

Sulastriyono (2014). Filosofi Pengakuan dan Penghormatan Negara Terhadap Masyarakat Hukum Adat di Indonesia. Jurnal Yudisial Edisi 90 September Desember 2014.

Tim Inkuiri Komisi Nasional Komnas HAM (2016). Hak Masyarakat Hukum Adat atas Wilayahnya di Kawasan Hutan. Jakarta. Komisi Nasional Hak Asasi Manusia Republik Indonesia.

Tim Konsorsium Pembaruan Agraria (2015). Reforma Agraria dan Penyelesaian Konflik Agraria Disandera Birokrasi. Laporan Penelitian KPA. 